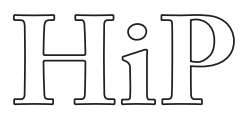

Historia i Polityka

Nr $13(20) / 2015$, ss. 47-63

ISSN 1899-5160

www.hip.umk.pl

DOI: http://dx.doi.org/10.12775/HiP.2015.003

Katarzyna GA£A

Uniwersytet Warszawski

\title{
Od konfrontacji do kooperacji - ewolucja postawy ONZ w stosunku do korporacji transnarodowych
}

\author{
From Confrontation to Cooperation - the Evolution of the UN's Attitude \\ towards Transnational Corporations
}

\begin{abstract}
Transnational corporations started to play more and more important role in the international relations, along with accelerating globalization and the growing meaning of the soft, nonmilitary sources of power. The UN made several attempts to regulate transnational business activities by working on appropriate legal solutions. One of them concerned establishing the Code of Conduct for transnational corporations. Gradually, it started to be clear that the differences in the states interests and the opportunities that were offered to corporations by globalization made it difficult to introduce effective mechanisms to limit and control international enterprises. There was a need to change the UN's attitude towards these actors from confrontation to cooperation, what was reflected by the creation of the Global Compact initiative. In this article there is analyzed the evolution of the UN's approach to transnational corporations - its genesis, course, and results.
\end{abstract}

Keywords: the UN, transnational corporations, the Code of Conduct, the Global Compact Słowa kluczowe: ONZ, korporacje transnarodowe, Generalny Kodeks Postępowania, Global Compact

ONZ od początku swojego istnienia przejawiało zainteresowanie kwestiami społeczno-gospodarczymi. Obligowały ją do tego zapisy Karty Narodów Zjednoczonych, w tym między innymi artykuł 1, który określał, że jednym z celów ONZ jest „doprowadzenie do współdziałania międzynarodowego w rozwiązywaniu zagadnień o charakterze gospodarczym, społecznym, kulturalnym lub humanitarnym (...)”. Naturalną konsekwencją podjęcia przez ONZ powyższych zagadnień było zwrócenie uwagi na działalność korporacji transnarodowych, tym bardziej że ich pozycja jako uczestnika międzynarodowych stosunków politycznych i gospodarczych nieustannie rosła. Celem tego artykułu jest analiza przeobrażeń, jakie można było zaobserwować w postawie ONZ względem funkcjonujących ponad granicami państw przedsiębiorstw. Zmiany te polegały na przejściu od kon- 
frontacji, która dominowała w stosunkach między obydwiema stronami w latach siedemdziesiątych XX wieku do zacieśniania współpracy w pierwszym dziesięcioleciu XXI wieku. W tym kontekście za kluczowe należy uznać dwie następujące kwestie: co zaważyło na takim, a nie innym kształtowaniu się podejścia ONZ do korporacji transnarodowych oraz jakie były skutki prezentowanej względem nich postawy. Nie sposób jednak mówić o poglądach ONZ na działalność korporacji, nie podejmując wcześniej próby scharakteryzowania tych podmiotów oraz przedstawienia wyzwań, jakie stawiają one współczesnemu światu.

\section{Korporacje transnarodowe}

\section{jako uczestnicy stosunków międzynarodowych}

Mimo, że początki istnienia korporacji transnarodowych sięgają XVI i XVII wie$\mathrm{ku}^{1}$, to jednak ostatnie dekady XX wieku uważa się za najbardziej znamienny okres w ich historii. Szacuje się, że w 1970 roku istniało około 7 tysięcy korporacji transnarodowych ${ }^{2}$, podczas gdy w 1999 roku było ich już blisko 63 tysiące ${ }^{3}$. W przeciągu trzydziestu lat ich liczba wzrosła zatem dziewięciokrotnie, a w 2010 roku przekroczyła $100000^{4}$. Thomas L. Friedman wyjaśniając przyczyny tego zjawiska, posłużył się pewnym obrazowym porównaniem. Jego zdaniem świat okresu zimnej wojny przypominał "rozległą równinę poprzecinaną płotami, murami, zasiekami i ślepymi drogami"', które stanowiły liczne bariery natury politycznej, ekonomicznej i ideologicznej, ograniczające możliwości działania i rozwoju międzynarodowej przedsiębiorczości. Wraz z końcem dwubiegunowego układu sił, zaczęła wyłaniać się otwarta, zintegrowana, wolna od wielu ograniczeń „równina” wolnego rynku, która stała się dla „elektronicznego stada”, jakim to mianem okre-

\footnotetext{
${ }^{1}$ Najczęściej przyjmuje się, że pierwszymi korporacjami transnarodowymi były szesnastoi siedemnastowieczne kompanie handlowe zakładane w państwach Europy Zachodniej w celu prowadzenia wymiany gospodarczej z koloniami. Niektórzy badacze doszukują się początków przedsiębiorstw międzynarodowych w działalności handlowej starożytnych Fenicjan lub w praktykach bankowych templariuszy w XII w. Więcej o historii korporacji transnarodowych w: A. Zorska, Korporacje transnarodowe: przemiany, oddziatywania, wyzwania, Warszawa 2007, s. 73-91.

2 UNCTAD, World Investment Report 1993: Transnational Corporations and Integrated International Production, New York 2000, s. 2.

${ }^{3}$ UNCTAD, World Investment Report 2000: Cross-border Mergers and Acquisitions and Development, New York 2000, s. XV.

${ }^{4}$ UNCTAD, World Investment Report 2012: Towards a New Generation of Investment Policies, Annex table 34, http://unctad.org/Sections/dite_dir/docs/WIR11_web\%20tab\%2034.pdf, odczyt z 14.11.2014.

5 T.L. Friedman, Lexus i drzewo oliwne. Zrozumieć globalizacje, Poznań 2001, s. 70.
} 
śla Friedman korporacje transnarodowe, dogodnym środowiskiem, gdzie mogły się „żywić, rosnąć, mnożyć i w końcu gromadzić w potężne superrynki”.

Badacze przedmiotu wskazują, że naukowe poznanie tych podmiotów wymaga wielowymiarowego i interdyscyplinarnego podejścia, gdyż korporacje transnarodowe wraz ze wzrostem roli, jaką odgrywają we współczesnym świecie, obejmują swoim wpływem coraz więcej sfer życia ${ }^{7}$. Przedsiębiorstwa te często są postrzegane jako najbardziej skomplikowany i trudny do jednoznacznego sklasyfikowania podmiot stosunków międzynarodowych ${ }^{8}$. Znajduje to swoje odzwierciedlenie między innymi w wielości terminów, którymi się je określa. W literaturze przedmiotu stosuje się nazwy: korporacje lub przedsiębiorstwa międzynarodowe, wielonarodowe, transnarodowe, ponadnarodowe czy globalne.

W dokumentach ONZ najczęściej używane jest pojęcie: „korporacja transnarodowa”, przez które rozumie się „przedsiębiorstwo, które posiada i kontroluje aktywa fabryk, kopalń, biur sprzedaży i innych jednostek w dwóch lub więcej krajach"’. Inna oenzetowska definicja podaje, że korporacje transnarodowe to przedsiębiorstwa, „będące spółką kapitałową, które składają się z przedsiębiorstw macierzystych i ich filii zagranicznych" ${ }^{10}$. Firma macierzysta to przedsiębiorstwo, kontrolujące aktywa innych jednostek w krajach poza krajem macierzystym, zazwyczaj poprzez posiadanie udziału w kapitale akcyjnym tych podmiotów. Udział ten, wynoszący co najmniej $10 \%$ zwykłych akcji, lub prawo głosu na walnym zebraniu akcjonariuszy traktuje się zazwyczaj jako granicę kontroli aktywów. Za filię zagraniczną uważa się natomiast spółkę kapitałową, w której inwestor - będący rezydentem innego kraju - ma udział kapitałowy, umożliwiający trwały wpływ na zarządzanie tym przedsiębiorstwem ${ }^{11}$.

Atrybuty korporacji transnarodowych, które są istotne przy rozpatrywaniu ich jako uczestników stosunków międzynarodowych to ${ }^{12}$ :

- międzynarodowy zasięg i charakter działania,

- brak suwerenności czyli takich cech jak samowładność i całowładność,

${ }^{6}$ Ibidem, s. 153.

7 K. Piórko, „Wtadza” korporacji transnarodowych w stosunkach międzynarodowych, Toruń 2008, s. 29.

${ }^{8}$ T. Łoś-Nowak, Stosunki międzynarodowe. Teorie - systemy-uczestnicy, Wrocław 2000, s. 249.

9 UNCTAD, Transnational Corporations in World Development: A Re-examination, New York 1978 , s. 6.

${ }^{10}$ UNCTAD, World Investment Report 2004: The Shift Towards Services, New York and Geneva 2004, s. 345.

${ }^{11}$ Ibidem, s. 345.

12 A. Jarczewska-Romaniuk, Przedsiębiorstwa międzynarodowe, Bydgoszcz-Warszawa 2004, s. 86. 
- zdolność do samodzielnego działania w skali międzynarodowej oraz oddziaływania na stosunki międzynarodowe i na ich uczestników,

- umiędzynarodowiona struktura organizacyjna o różnym stopniu centralizacji,

- celowa działalność ukierunkowana na maksymalizację zysków, która warunkuje ich przetrwanie.

W swoich działaniach korporacje transnarodowe bazują na tzw. miękkich źródłach siły czyli na swoim potencjale ekonomicznym, organizacyjnym, naukowym i technologicznym. Według szacunków UNCTAD w 2010 roku produkcja przedsiębiorstw międzynarodowych mierzona wartością dodaną wyniosła 16 bilionów dolarów, co stanowiło ponad 1/4 światowego produktu krajowego brutto ${ }^{13}$. Łączna wartość globalnych zasobów zagranicznych inwestycji bezpośrednich, będących podstawą międzynarodowej produkcji, przekroczyła w 2011 roku 20 bilionów dolarów ${ }^{14}$. W tym samym roku wartość wydatków, które zostały przeznaczone na badania i rozwój przez 1500 najbardziej liczących się w tej dziedzinie przedsiębiorstw wyniosła 510 mld euro ${ }^{15}$. Dane te w połączeniu z takimi cechami jak: duża mobilność, zdolności adaptacyjne oraz umiejętność wpływania na zachowania innych uczestników stosunków międzynarodowych skłaniają do uznania korporacji transnarodowych za specyficzne podmioty władzy w stosunkach międzynarodowych ${ }^{16}$. W tym kontekście warto przytoczyć wypowiedź sekretarza generalnego Amnesty International - Pierre’a Sane, który mówiąc o działaniach swojej organizacji zauważył: „Dawniej mogliśmy wpływać na korporacje za pośrednictwem rządów, dziś coraz częściej zdarza nam się wpływać na rządy za pośrednictwem wielkich korporacji. Władza przesuwa się w stronę gospodarki” ${ }^{17}$. Korzystając z tego, podmioty międzynarodowego biznesu działają na rzecz upowszechnienia liberalnego porządku na świecie, który ma stymulować i jednocześnie uzasadniać rozwój globalizacji, deregulację gospodarek narodowych oraz redukcję funkcji państwa ${ }^{18}$. Ich aktywność na tym polu wzbudza wiele kontrowersji. Za uprawnione należy

${ }^{13}$ UNCTAD, World Investment Report 2011: Non-Equity Modes of International Production and Development, New York-Geneva 2011, s. 24.

${ }_{14}$ UNCTAD, World Investment Report 2012: Towards a New Generation of Investment Policies, New York-Geneva 2012, s.2.

15 European Commission, EU R\&D Scoreboard: The 2012 EU Industrial R\&D Investment Scoreboard, Luxembourg 2012, s. 17.

${ }^{16}$ M. Lech, Zdolność oddziaływania korporacji transnarodowych na wspótczesne stosunki międzynarodowe w dobie procesu globalizacji, [w:] Korporacje transnarodowe: jeden temat, różne spojrzenia, red. J. Menkes, T. Gardocka, Warszawa 2010, s. 216.

${ }_{17}$ J. Żakowski, Prawa człowieka. Dzisiaj Pekin, jutro Paryż, autoryzowany wywiad z sekretarzem generalnym Amnesty International - Pierre Sane, Gazeta Wyborcza, 5-6.08.2000, s. 8.

${ }_{18}$ M. Pietraś, Globalizacja jako proces zmiany społeczności międzynarodowej, [w:] Oblicza procesów globalizacji, red. M. Pietraś, Lublin 2002, s. 41. 
uznać obawy, sugerujące, że korporacje transnarodowe zyskują nadmierny wpływ na życie gospodarcze, polityczne i społeczne współczesnego świata. Wachlarz zarzutów, jakie stawia się przedsiębiorstwom jest bardzo szeroki i obejmuje takie kwestie jak: ograniczanie suwerenności państw, łamanie praw człowieka i standardów ochrony środowiska, stosowanie korupcji oraz przyczynianie się do nierównomiernego rozwoju społeczno-gospodarczego i niestabilności światowej gospodarki.

\section{Okres konfrontacji ONZ z korporacjami transnarodowymi}

W pierwszych latach swojego funkcjonowania ONZ koncentrowało się na polityce bezpieczeństwa i na rozbrojeniu, rzadziej natomiast podejmowało zagadnienia społeczno-gospodarcze, w tym problem korporacji transnarodowych. Rezolucje Zgromadzenia Ogólnego, jeśli odnosiły się do przedsiębiorstw międzynarodowych, to głównie w sposób pośredni ${ }^{19}$. Utworzenie w 1964 roku Konferencji Narodów Zjednoczonych ds. Handlu i Rozwoju (UNCTAD) - organu, zajmującego się sprawami związanymi ze światowym przepływem towarów, finansami i inwestycjami zagranicznymi, można uznać za jeden z pierwszych zwiastunów większego zainteresowania się ONZ problematyką międzynarodowej przedsiębiorczości.

Wraz ze wzrostem w latach siedemdziesiątych znaczenia krajów rozwijających się coraz więcej miejsca w dyskusjach na forum ONZ, zaczęto poświęcać korporacjom transnarodowym. Państwa Trzeciego Świata były negatywnie do nich nastawione i domagały się wypracowania zespołu norm, które mogłyby uregulować działanie tych funkcjonujących ponad granicami państw podmiotów. Korporacjom zarzucano eksploatacyjny charakter prowadzonych działań, przejmowanie kontroli nad poszczególnymi sektorami gospodarek oraz osłabianie suwerenności państw. Opinie te były podzielane przez wielu ówczesnych badaczy i dziennikarzy ekonomicznych, a ostrze krytyki skierowano przede wszystkim przeciwko przedsiębiorstwom amerykańskim. Duży rozgłos zdobyła książka Jean-Jacques’a Servana-Schreibera pod tytułem Le Défi Américain (Amerykańskie wyzwanie), w której autor postawił tezę, że kontrolowane w Europie przez Amerykanów przedsiębiorstwa stanowią trzecią gospodarkę świata po USA i Europie ${ }^{20}$. Inni starali się udo-

19 Przykładowo w preambule Powszechnej Deklaracji Praw Człowieka zastrzeżono, że „wszyscy ludzie i wszystkie organy społeczeństwa” powinni respektować zawarte w Deklaracji postanowienia. Natomiast w Konwencji przeciwko ludobójstwu z 1948 r. stwierdza się, że „winni ludobójstwa (...) będą karani bez względu na to, czy są konstytucyjnie odpowiedzialnymi członkami rządu, funkcjonariuszami publicznymi czy też osobami prywatnymi”.

20 Zob. J.J. Servan-Schreiber, Le Défi Américain, Paris 1967 (Wyd. amerykańskie: The American Challenge, New York 1968). 
wodnić, że działalność międzynarodowych przedsiębiorstw przyczynia się do nierównomiernego rozwoju świata ${ }^{21}$ oraz sygnalizowali, że poprzez swoje strategie cenowe korporacje transnarodowe przyczyniają się do utraty części dochodów przez kraje rozwijające $\operatorname{się}^{22}$.

Wrogość państw do przedsiębiorstw międzynarodowych była umotywowana coraz częstszymi przypadkami ingerencji zagranicznych koncernów w ich suwerenność. Szerokim echem odbiły się zwłaszcza wydarzenia w Chile, gdzie w 1973 roku demokratycznie wybrany prezydent Salvador Allende został pozbawiony władzy na rzecz przywódcy junty wojskowej - Augusta Pinocheta w skutek działań amerykańskiego koncernu telekomunikacyjnego ITT, obawiającego się nacjonalizacji jednej ze swoich chilijskich spółek. Co ciekawe, wydarzenia te miały miejsce rok po tym, jak stolica Chile była gospodarzem trzeciej sesji UNCTAD, na której głoszono prawo krajów rozwijających się do regulowania kwestii związanych z inwestycjami zagranicznymi oraz do zapobiegania ich negatywnym skutkom.

Pod presją państw Trzeciego Świata Zgromadzenie Ogólne przyjęło w latach siedemdziesiątych szereg rezolucji, które miały w założeniu ograniczyć niektóre praktyki korporacji transnarodowych i zwiększyć nad nimi kontrolę. Dokumenty te powstawały w ramach Nowego Międzynarodowego Ładu Ekonomicznego (NMŁE), który propagował przebudowanie systemu światowej gospodarki tak, aby zmniejszyła się luka rozwojowa między krajami bogatymi, a biednymi. W deklaracji o utworzeniu Nowego Ładu zapisano, że państwa są uprawnione do regulowania i kontrolowania aktywności międzynarodowych korporacji działających na ich terenie oraz mają swobodę w nacjonalizacji lub wywłaszczaniu zagranicznych aktywów na korzystnych dla siebie warunkach ${ }^{23}$. Zasady te zostały także włączone w treść Karty Ekonomicznych Praw i Obowiązków Państw w 1974 roku, zaś w 1975 roku Zgromadzenie Ogólne przyjęło rezolucję potępiającą praktyki korupcyjne stosowane przez korporacje, a jednocześnie zachęcającą rządy do stawiania przed sądem wszystkich podmiotów światowego biznesu, które się takich praktyk dopuszczają ${ }^{24}$.

Należy w tym miejscu zaznaczyć, że rezolucje dotyczące NMŁE nie miały formalnie mocy wiążącej i były aktami tzw. miękkiego prawa. Mogły zatem prze-

${ }^{21}$ Zob. S.H. Hymer, The Multinational Corporation and the Law of Uneven Development, [w:] Economics and the World Order, red. J. Bhagwati, London 1972, s. 113-140.

22 Zob. C.V. Vaitsos, The Process of Commercialization of Technology in the Andean Pact, [w:] International Firms and Modern Imperialism, red. H. Radice, London 1975, s. 183-214.

${ }^{23}$ Declaration on the Establishment of a New International Economic Order, Resolution $3201\left(^{\text {th }}\right.$ Special Session), 1 May 1974, art. 4.

${ }^{24}$ Vide Measures Against Corrupt Practices of Transnational and Other Corporations, Their Intermediaries and Others Involved, Resolution 3514 (XXX), 15 $5^{\text {th }}$ December 1975. 
kształcić się w normy prawa międzynarodowego tylko poprzez zawieranie umów międzynarodowych, służących wykonaniu rezolucji ONZ lub na skutek wprowadzenia przez państwa do ustawodawstwa wewnętrznego zalecanych w rezolucjach zapisów ${ }^{25}$. Próby przełożenia NMŁE na grunt prawa międzynarodowego zakończyły się jednak niepowodzeniem. Okazało się, że kraje rozwijające się mimo liczebnej przewagi w Zgromadzeniu Ogólnym ONZ nie były w stanie wymusić na państwach wysoko rozwiniętych realizacji uchwalonych rezolucji.

Równolegle do działań zmierzających do unormowania aktywności przedsiębiorstw międzynarodowych, ONZ podjęło w latach siedemdziesiątych prace badawcze na ich temat. W 1972 roku Rada Społeczno-Gospodarcza ONZ (ECOSOC) powołała specjalną grupę ekspertów, która miała wypracować wspólne stanowisko w tej materii. Tagi Sagafi-Nejad, przywołując okoliczności, w jakich pracowali eksperci w tym burzę, która powstała wokół korporacji transnarodowych w latach siedemdziesiątych, stwierdziła, że oenzetowska grupa ekspertów prezentowała "tęczę poglądów w samym oku cyklonu” ${ }^{26}$. Przedstawiciele biznesu oraz badacze, pochodzący z krajów wysoko rozwiniętych przekonywali, że większość zarzutów stawianych korporacjom jest wyolbrzymiona i nie znajduje solidnego uzasadnienia. Ci zaś eksperci, którzy wywodzili się z krajów rozwijających się, koncentrowali się głównie na negatywnych skutkach aktywności przedsiębiorstw i eksponowali konieczność ograniczania ich oraz kontrolowania. Zdaniem Johna Dunninga, uczestnika tamtych debat, największym osiągnięciem grupy ekspertów było przyczynienie się do powstania dwóch instytucji, które miały na bieżąco zajmować się problematyką korporacji transnarodowych ${ }^{27}$.

Pierwsza z nich - Międzynarodowa Komisja ds. Korporacji Transnarodowych (UN Commission on Transnational Corporations) - stanowiła międzyrządowy organ pomocniczy ECOSOC oraz główne forum dyskusji w systemie Narodów Zjednoczonych nad przedsiębiorstwami międzynarodowymi. Posiedzenia komisji zwoływane były raz w roku, a jej członkowie byli wybierani według klucza geograficznego ${ }^{28}$. Komisja miała dążyć do wypracowania wśród państw wspólnych opinii i stanowisk na temat kwestii dotyczących międzynarodowej aktywności

25 J. Menkes, Nowy Międzynarodowy Ład Ekonomiczny. Studium prawnomiędzynarodowe, Katowice 1988 , s. 125.

26 T. Sagafi-Nejad, The UN and Transnational Corporations: From Code of Conduct to Global Compact, Bloomington 2008, s. 86.

27 Ibidem, s. 86.

2812 członków komisji pochodziło z państw Afryki, 11 z państw Azji, 10 z państw latyno-amerykańskich, 5 z państw Europy Środkowo-Wschodniej i 10 z Europy Zachodniej oraz pozostałych państw. 
przedsiębiorstw. Wyposażono ją również w mechanizmy pozwalające na wymianę poglądów między reprezentującymi rządy członkami komisji, a organizacjami pozarządowymi, związkami zawodowymi, przedstawicielami biznesu, konsumentów i innych grup społecznych ${ }^{29}$.

Druga instytucja - Centrum ONZ ds. Korporacji Transnarodowych (UN Centre on Transnational Corporations) - była autonomicznym organem Sekretariatu ONZ, odpowiedzialnym za wspieranie prac wspomnianej wyżej komisji oraz podejmowanie rozmaitych badań z zakresu przedsiębiorstw międzynarodowych. O ile w komisji zasiadali przedstawiciele rządów, tutaj skład stanowili eksperci i badacze przedmiotu. Centrum miało wypełniać trzy podstawowe funkcje: informacyjną, analityczną i doradczą. Dzięki jego staraniom ONZ poszerzało swój zasób wiedzy na temat międzynarodowej aktywności przedsiębiorstw oraz najważniejszych zmian w prawie i polityce państw dotyczących korporacji transnarodowych. W obszarze zainteresowań Centrum znajdowało się badanie wpływu przedsiębiorstw międzynarodowych na rozwój społeczno-gospodarczy i stosunki międzynarodowe, analizowanie roli tych podmiotów z perspektywy mikroi makroekonomicznej oraz prowadzenie badań istotnych w kontekście opracowania międzynarodowych standardów działania dla korporacji transnarodowych ${ }^{30}$.

Grupa ekspertów, która wnioskowała za utworzeniem komisji i centrum badawczego zakładała, że będą to odpowiednie instytucje do podjęcia prac nad projektem kodeksu, regulującego działalność korporacji.

\section{Prace nad Generalnym Kodeksem Postępowania i przewartościowanie podejścia ONZ do korporacji transnarodowych}

Generalny Kodeks Postępowania (ang. Code of Conduct) miał wyjść naprzeciw oczekiwaniom większości państw, które domagały sie ustanowienia przejrzystych zasad funkcjonowania międzynarodowych przedsiębiorstw. W założeniu, kodeks ten powinien być odpowiednikiem układu GATT w zakresie zagranicznych inwestycji. Punkt wyjścia stanowiły zalecenia oenzetowskiej grupy ekspertów, według której mimo, że kodeks „nie miałby wiążącego charakteru, służyłby jako ważny instrument moralnej perswazji, wzmocnionej autorytetem międzynarodowych organizacji oraz poparciem opinii publicznej"31. Kraje rozwinięte zgadzały się z tą

${ }^{29}$ Zob. ECOSOC, Resolution No 1913, 5th December 1974.

${ }^{30}$ Zob. ECOSOC, Resolution No 1908, 5th December 1974.

${ }^{31}$ ECOSOC, Possible Methods of Work Related to the Drafting of a Code of Conduct, 19 January 1976, s. 2, http:// unctc.unctad.org/data/ec1010a.pdf, odczyt z 14.11.2014. 
wizją kodeksu i sprzeciwiały się nadaniu mu bardziej rygorystycznego charakteru. Co więcej, lobbowały za umieszczeniem w nim zapisów, które gwarantowałyby zagranicznym inwestorom określone prawa oraz wskazywały na zobowiązania, jakie względem nich mają państwa przyjmujące. Z kolei większość krajów rozwijających się chciała, aby kodeks był prawnie wiążącym dokumentem, a jego treść wypełniały przepisy, ograniczające dotychczasową swobodę przedsiębiorstw międzynarodowych.

W 1982 roku po trwających prawie dziesięć lat negocjacjach projekt kodeksu został przedstawiony Międzynarodowej Komisji ds. Korporacji Transnarodowych. Była w nim mowa o obowiązku respektowania przez przedsiębiorstwa praw człowieka i suwerenności państw oraz o zakazie stosowania przez zagraniczne firmy praktyk korupcyjnych i innych działań szkodzących konsumentom, pracownikom czy środowisku naturalnemu. Jednocześnie wspominano także o zapewnianiu przez rządy państw trwałości i przejrzystości przepisów prawa, wpływających na funkcjonowanie przedsiębiorstw międzynarodowych oraz o odszkodowaniach dla zagranicznych inwestorów w przypadku znacjonalizowania ich majątku. Analiza kolejnych wersji tego dokumentu, które powstawały w toku dalszych negocjacji, pozwala stwierdzić, że w centrum sporu znajdowały się dwa słowa: „będą” (ang. shall) czy „powinny” (should), używane w kontekście zobowiązań korporacji i państw. Ponieważ komisji nie udało się osiągnąć konsensusu w sprawie zasad, na jakich kodeks miał wejść w życie, kraje rozwijające się i Sekretariat ONZ doprowadziły do przejęcia dalszych prac nad tym dokumentem przez ECOSOC. W 1992 roku przedłożono go Zgromadzeniu Ogólnemu, gdzie również niepowodzeniem zakończyły się próby wypracowania porozumienia. W tej sytuacji specjalne powołana grupa międzyrządowa zaleciła, aby zaniechać dalszych prac nad tym dokumentem i podjąć działania, zmierzające do opracowania alternatywnej formy regulacji działalności korporacji transnarodowych.

Mimo, że prace nad kodeksem zostały przerwane, nie należy umniejszać roli, jaką odegrał on w kształtowaniu relacji między ONZ, a środowiskiem światowego biznesu ${ }^{32}$. Czynniki, które zadecydowały o fiasku porozumienia, stanowiły jednocześnie zapowiedź zmian, jakie musiało wkrótce podjąć ONZ, aby zwiększyć szanse na wypracowanie konsensusu wokół korporacji. Główną przyczyną niepowodzenia prac nad kodeksem było ich upolitycznienie. Kraje rozwijające się traktowały go jako element strategii, zmierzającej do ustanowienia nowego międzyna-

32 Warto zauważyć, że kilka lat po przerwaniu prac nad Generalnym Kodeksem Postępowania, fiaskiem zakończyły się także negocjacje prowadzone na forum OECD nad innym dokumentem regulującym działalność przedsiębiorstw międzynarodowych - Wielostronnym Porozumieniem Inwestycyjnym (Multilateral Agreement on Investment - MAI). 
rodowego ładu, podczas gdy kraje wysoko rozwinięte odbierały tego rodzaju działania jako zagrożenie dla ich interesów narodowych. Najbardziej krytyczne w stosunku do przygotowywanego dokumentu były USA ${ }^{33}$, gdzie dominował pogląd wyrażony w Wall Street Journal przez Juliane Pilon, która twierdziła, że kodeks ten prezentuje wrogie podejście do prywatnej przedsiębiorczości ${ }^{34}$.

Do upolitycznienia prac nad kodeksem przyczyniło się powierzenie ich komisji, której skład stanowili przedstawiciele rządów. Reprezentowali oni w pierwszej kolejności doraźne interesy swoich państw, stąd brakowało im motywacji do szerszego oraz bardziej dalekowzrocznego spojrzenia na poruszane kwestie. Za uzasadnione należało uznać opinie sugerujące, że sprawą międzynarodowych przedsiębiorstw powinny się zająć mniej upolitycznione organy takie jak Sekretariat i Sekretarz Generalny ONZ. Wraz z zaprzestaniem prac nad projektem upadła także wizja tworzenia kolejnych dokumentów o tak restrykcyjnym charakterze. Większe szanse powodzenia mogły mieć te projekty, które w znacznym stopniu uwzględniałyby opinie i uwagi, wyrażane przez przedstawicieli biznesu, a zatem powstawały w atmosferze kooperacji, a nie konfrontacji ${ }^{35}$. Z kolei, Kathryn Sikkink zwraca uwagę na fakt, że tempo prac nad kodeksem było zbyt wolne, a zakres prowadzonych negocjacji za szeroki, by zakończyły się one sukcesem ${ }^{36}$.

Najważniejszym jednak czynnikiem, który zadecydował o zaprzestaniu dalszych konsultacji nad tym projektem, była powszechnie podzielana świadomość, że zmiany, jakie zaszły w świecie, a zwłaszcza w światowej gospodarce na skutek globalizacji, wymagały zupełnie nowego spojrzenia na kwestię regulacji działań przedsiębiorstw międzynarodowych. Przede wszystkim obserwowano wzrost znaczenia miękkich, pozawojskowych źródeł siły w postaci potencjału ekonomicznego i technologicznego. Kraje rozwijające się, w większości wrogo dotychczas nastawione do międzynarodowego biznesu, zaczęły w obliczu coraz poważniejszych problemów z biedą i niedorozwojem, przychylniej patrzeć na zagraniczne inwestycje i widzieć w nich szansę na pozyskanie kapitału i nowoczesnych technologii. Mimo, że na forum ONZ państwa te nadal prezentowały krytyczne wobec kor-

33 Niechęć amerykańskiej administracji do tego projektu została wyraźnie zaakcentowana w 1986 r., kiedy Departament Stanu ogłosił zamiar ograniczenia swojego zaangażowania w aktywność oenzetowskiego centrum badawczego do spraw korporacji transnarodowych oraz zalecał podobne posunięcie przedstawicielom amerykańskich przedsiębiorstw.

34 J.G. Pilon, Just when U.N. is in Range, Wall Street Journal, 28 September 1986, s. 32, cyt. za: T. Sagafi-Nejad, op. cit., s. 110.

35 UNCTC, Transnational Corporations in World Development: Trends and Prospects, New York, 1988, s. 3, http://unctc.unctad.org/data/e88iia7a.pdf, odczyt z 14.11.2014.

${ }^{36}$ K. Sikkink, International Codes of Conduct for Transnational Corporations: The Case of the WHO / UNICEF Code, International Organization 1986, nr 4 (40), s. 832. 
poracji stanowisko, w realnej polityce skłonne były do coraz większych ustępstw, licząc na to, że uda się im w ten sposób przyciągnąć zagranicznych inwestorów.

Zdaniem Hansa Janssona na ten stan rzeczy miała też wpływ postawa samych przedsiębiorstw, które często decydowały się na dostosowanie swoich strategii do potrzeb gospodarek krajów przyjmujących ${ }^{37}$. W kręgach biznesowych coraz częściej mówiło się o idei społecznej odpowiedzialności przedsiębiorstw, zgodnie z którą celem aktywności gospodarczej jest dążenie do długofalowego i zróżnicowanego rozwoju firmy przy poszanowaniu zasad ekonomii, ekologii i etyki. Wzrost popularności tej koncepcji bazował na przekonaniu, że dzięki niej korporacje wzmocnią fundamenty, na których opiera się społeczne przyzwolenie na ich działalność.

ONZ, obserwując zachodzące na arenie międzynarodowej zmiany, coraz bardziej skłaniało się ku wypracowaniu bardziej partnerskich relacji ze środowiskiem biznesu. Istotną rolę w przewartościowaniu polityki ONZ względem przedsiębiorstw odegrali Sekretarze Generalni, urzędujący w latach dziewięćdziesiątych. Boutros Ghali uważał, że wzrost znaczenia korporacji transnarodowych jest jednym z pozytywnych efektów globalizacji i czuł się zobligowany do tego, aby umożliwić im włączenie się do działań na rzecz rozwiązywania problemów współczesnego świata ${ }^{38}$. Równocześnie zależało mu na reformie organizacyjnej ONZ, która miała zwiększyć efektywność tej instytucji. W 1993 roku zapadła decyzja o wcieleniu oenzetowskiego Centrum ds. Korporacji Transnarodowych do UNCTAD. Utworzone w latach siedemdziesiątych Centrum mimo, że znacząco przyczyniło się do rozwoju badań nad korporacjami, było kojarzone z epoką, kiedy dominowała na forum ONZ negatywna opinia na ich temat. Przeniesienie tej instytucji z Nowego Jorku do Genewy i jej późniejszą marginalizację można traktować, jako symboliczne odcięcie się od poprzedniej postawy ONZ, nastawionej na konfrontację z międzynarodowym biznesem ${ }^{39}$.

${ }^{37}$ H. Jansson, M. Saqib, D. Deo Sharma, The State and Transnational Corporations: A Network Approach to Industrial Policy in India, Brookfield 1995, s. 5.

${ }^{38}$ UN Secretary General, Secretary-General in Lecture at Oxford, Speaks of Globalization, Fragmentation And Consequent Responsibilities on UN, Press Release SG/SM/5870/Rev.1, 12 January 1996, http://www.un.org/ press/en/1996/19960112.sgsm5870.html, odczyt z 14.11.2014.

39 Tagi Sagafi-Nejad, na podstawie przeprowadzonych wywiadów z byłymi pracownikami Centrum wysnuwa wniosek, że na taki bieg wydarzeń miała w dużej mierze wpływ niechęć USA do Centrum. Boutros Ghali potrzebował poparcia Amerykanów przy restrukturyzacji ONZ, dlatego wyszedł naprzeciw ich oczekiwaniom i pozbawił autonomiczności instytucję, która była ich zdaniem zbyt krytyczna w stosunku do środowiska biznesu, T. Sagafi-Nejad, op. cit., s. 129-131. 


\section{Global Compact jako forma współpracy ONZ ze środowiskiem biznesu}

Zmiany wewnątrz systemu ONZ, które zapoczątkował Boutros Ghali, były kontynuowane przez jego następcę - Kofiego Annana. W ramach otwarcia ONZ na środowisko przedsiębiorców zaczął on współpracować z Międzynarodową Izbą Handlową (International Chamber of Commerce - ICC), największą organizacją biznesową na świecie. Zbliżenie to zainspirowało obydwie strony do podjęcia wspólnego, nowatorskiego przedsięwzięcia, które miało przełamać ich dotychczasową wrogość i nieufność. W styczniu 1999 roku Kofi Annan, występując na Światowym Forum Gospodarczym w Davos zaproponował powstanie nowej inicjatywy, dającej sektorowi prywatnemu możliwość włączenia się w aktywne zwalczanie zagrożeń i rozwiązywanie problemów społeczno-gospodarczych, wynikających z procesów globalizacji. Wezwał przedstawicieli biznesu do "globalnego porozumienia” (ang. global compact), które miało ukazać „ludzką twarz globalizacji” oraz stanowić kolejny krok na drodze do kreatywnego partnerstwa między ONZ, a światem biznesu. Annan przedstawiał tę inicjatywę jako uzupełnienie działań prowadzonych na gruncie międzypaństwowym. Wskazał na olbrzymi potencjał, jakim dysponuje światowy biznes i apelował do korporacji transnarodowych o podjęcie działań na rzecz wdrażania praw człowieka, standardów pracy i norm dotyczących ochrony środowiska naturalnego. Sekretarz Generalny wyraził przekonanie, że inicjatywa ta, mająca dobrowolny charakter, przyniesie lepsze rezultaty niż restrykcje nakładane odgórnie na międzynarodowy handel i zagraniczne inwestycje ${ }^{40}$.

Propozycja Annana została wcielona w życie 26 lipca 2000 roku, kiedy to w siedzibie głównej ONZ w Nowym Jorku pierwszych 50 przedstawicieli różnych korporacji podpisało zobowiązanie do wdrażania zasad Global Compact. W tym miejscu należy podkreślić, że o przekształceniu Global Compact w realną inicjatywę w przeciągu półtora roku od szczytu w Davos w dużej mierze zadecydowały wydarzenia związane z konferencją ministerialną WTO w Seattle w listopadzie 1999 roku, podczas której 30000 sympatyków różnych organizacji pozarządowych oraz 20000 przedstawicieli związków zawodowych ${ }^{41}$ wzięło udział w spektakularnej demonstracji w ramach „światowego dnia działania, oporu i karnawału przeciw-

${ }^{40}$ UN Secretary General, Secretary - General Proposes Global Compact on Human Rights, Labour, Environment, in Address to World Economic Forum in Davos, Press Release, SG/SM/6881, 1 February 1999, http://www.un. org/press/en/1999/19990201.sgsm6881.r1.html, odczyt z 14.11.2014.

41 Podaję dane za: G. Kell, J.G. Ruggie, Global Markets and Social Legitimacy: The Case of the 'Global Compact', York University, Toronto, Canada, 4-6 November 1999, http:/www.unglobalcompact.org /newsandevents/articles_and_papers/global_markets_social_legitimacy_york_university.html, odczyt z 14.11.2014. 
ko systemowi globalnego kapitalizmu"’22. Wydarzenie to stało się ikoną rosnącego w siłę ruchu społecznego nazwanego antyglobalizmem, który wyrażał sprzeciw wobec postępującej na bazie neoliberalnych haseł globalizacji, postrzeganej jako proces szkodliwy, prowadzący do powiększania się nierówności i niesprawiedliwości w świecie. Rozprzestrzeniające się na inne kraje protesty antyglobalistów, cieszyły się coraz większym poparciem opinii publicznej i uświadamiały korporacjom, że dotychczasowy model globalizacji ekonomicznej wyczerpuje się i należy poszukać innego rozwiązania. Inicjatywy takie jak Global Compact mogły w zaistniałej sytuacji stać się niezwykle użyteczne w odkrywaniu „ludzkiej twarzy biznesu”.

O tym jak duże zainteresowanie wzbudziło Global Compact w środowiskach biznesowych świadczy fakt, że już w trzy lata po utworzeniu inicjatywy liczyła ona ponad 1000 uczestników, natomiast w 2006 roku ich liczba przekroczyła $4000^{43}$. Według danych z 2014 roku w Global Compact zaangażowanych jest już ponad 12000 podmiotów ${ }^{44}$, co oznacza, że jest to największa inicjatywa społecznej odpowiedzialności biznesu. Większość uczestników Global Compact - $65 \%$ stanowią przedsiębiorstwa, pozostałe $35 \%$ to organizacje biznesowe, instytucje środowiska akademickiego, organizacje pracowników, miasta oraz różne organizacje pozarządowe ${ }^{45}$, które mają w założeniu poszerzać płaszczyznę dialogu i partnerstwa w obrębie inicjatywy.

Przedsiębiorstwo, pragnące zostać sygnatariuszem Global Compact musi wysłać do biura inicjatywy list, w którym wyraża poparcie dla jej zasad. Następnie firma jest zobowiązania do upubliczniania corocznych raportów, w których przedstawia, jakie podjęła działania w celu dostosowania się do wymogów Global Compact. Żadna z dziesięciu zasad nie może być naruszana przez przedsiębiorstwo, natomiast stopień i forma jego aktywności w zakresie aktywnego wdrażania wytycznych Global Compact jest uwarunkowana rzeczywistymi możliwościami działania, wiążącymi się z jego wielkością, rodzajem prowadzonej działalności gospodarczej czy też powiązaniami z innymi podmiotami. Firma powinna dokładać wszelkich starań, aby nieustannie doskonalić się w zakresie wspierania i realizacji zasad Global Compact.

Zasady te obejmują kilka obszarów tematycznych. Są to: prawa człowieka, standardy pracy, ochrona środowiska naturalnego i przeciwdziałanie korupcji.

42 The Battle in Seattle, The Economist, 25.11.1999, http://www.economist.com/node/261578, odczyt z 14.11.2014.

43 Global Compact Office, UN Global Compact. Annual Review. 2007 Leaders Summit, June 2007, s. 7.

${ }^{44}$ Global Compact Site, http://www.unglobalcompact.org/ParticipantsAndStakeholders/index.html, odczyt z 14.11.2014.

$45 \mathrm{http} / / /$ www.unglobalcompact.org/participants/search, odczyt z 14.11.2014. 
Opierają się one na czterech fundamentalnych dla tych zagadnień dokumentach: Powszechnej deklaracji praw człowieka, Deklaracji Międzynarodowej Organizacji Pracy o fundamentalnych zasadach i prawach pracy, Deklaracji z Rio o środowisku naturalnym i rozwoju Agenda 21 oraz Konwencji Narodów Zjednoczonych przeciwko korupcji. Zobowiązania, które przyjmują na siebie uczestnicy Global Compact, mają charakter zarówno pasywny, czyli wymagają powstrzymywania się od określonych zachowań, jak i aktywny, czyli polegają na podejmowaniu konkretnych działań na rzecz propagowanych przez inicjatywę standardów.

Tabela 1. Zasady Global Compact

\begin{tabular}{|l|}
\hline Prawa człowieka \\
\hline $\begin{array}{c}\text { Zasada 1. Popieranie i przestrzeganie praw człowieka przyjętych przez społeczność } \\
\text { międzynarodową. }\end{array}$ \\
\hline Zasada 2. Eliminacja wszelkich przypadków łamania praw człowieka przez firmę. \\
\hline Standardy pracy \\
\hline Zasada 3. Poszanowanie wolności stowarzyszania się. \\
\hline Zasada 4. Eliminacja wszelkich form pracy przymusowej. \\
\hline Zasada 5. Zniesienie pracy dzieci. \\
\hline Zasada 6. Efektywne przeciwdziałanie dyskryminacji w sferze zatrudnienia. \\
\hline Środowisko naturalne \\
\hline Zasada 7. Prewencyjne podejście do środowiska naturalnego. \\
\hline $\begin{array}{c}\text { Zasada 8. Podejmowanie inicjatyw mających na celu promowanie postaw } \\
\text { odpowiedzialności ekologicznej. }\end{array}$ \\
\hline Zasada 9. Stosowanie i rozpowszechnianie przyjaznych środowisku technologii. \\
\hline Przeciwdziałanie korupcji \\
\hline $\begin{array}{c}\text { Zasada 10. Przeciwdziałanie korupcji we wszystkich formach, w tym wymuszeniom } \\
\text { i łapówkarstwu }\end{array}$ \\
\hline
\end{tabular}

Źródło: Global Compact Network Poland, http://www.globalcompact.org.pl/Global-Compact/10-Zasad-GC, odczyt z 14.11.2014.

Na uwagę zasługuje fakt, że zasady Global Compact tylko w niewielkiej części pokrywają się treściowo z projektem Generalnego Kodeksu Postępowania. Pomijają kwestie związane z suwerennością państw i w większym stopniu koncentrują się na prawach jednostki. Przyczyn takiego stanu rzeczy należy szukać nie tylko w słabnącej pozycji państw, ale również w przewartościowaniu podejścia ONZ do kwestii rozwoju. Koncepcje takie jak rozwój ludzki, rozwój zrównoważony czy bezpieczeństwo ludzkie, które zostały opracowane przez agendy ONZ w ostat- 
nich dekadach XX wieku, eksponują człowieka, a nie państwo jako głównego beneficjenta rozwoju. Ponadto, tak jak w latach siedemdziesiątych najbardziej nagłaśniane były przypadki ingerencji korporacji w wewnętrzne sprawy państw, tak w latach dziewięćdziesiątych najczęściej wybuchały wokół przedsiębiorstw skandale związane z łamaniem praw człowieka, praw pracowniczych, standardów ochrony środowiska oraz ze stosowaniem praktyk korupcyjnych. Upowszechnianiem informacji na temat nieetycznych zachowań przedsiębiorstw zajęły się różne grupy organizacji społeczeństwa obywatelskiego, które przejęły od krajów rozwijających się funkcję głównego krytyka korporacji transnarodowych.

Zarówno ONZ, jak i przedsiębiorstwa podejmujące z nim współpracę, liczyły na to, że Global Compact przyczyni się do poprawy wizerunku międzynarodowego biznesu i przekona opinię publiczną o korzyściach wynikających z jego aktywności. Jednak z perspektywy ponad 10 lat istnienia inicjatywy wyraźnie widać, że cel ten nie został osiągnięty. Choć Global Compact zgromadziło wokół siebie stosunkowo dużą liczbę przedsiębiorstw i zapewniło rozgłos idei społecznej odpowiedzialności biznesu, trudno mówić o sukcesie inicjatywy, zwłaszcza w kontekście niedawnego kryzysu gospodarczego, który został spowodowany w głównej mierze nieetycznym zachowaniem przedstawicieli biznesu. Nie maleje też liczba nagłaśnianych przez media przypadków łamania przez przedsiębiorstwa praw człowieka i innych standardów. Co gorsza, zarzuty o nieetyczne postępowanie stawiane są także uczestnikom Global Compact. Na przykład koncern paliwowy BP, będący jedną z pierwszych firm, które przystąpiły do Global Compact, spowodował w 2010 roku niezwykle poważną w skutkach katastrofę ekologiczną w Zatoce Meksykańskiej przez niezachowanie odpowiednich standardów ochrony środowiska na swojej platformie wiertniczej ${ }^{46}$. Kilkoro innych uczestników Global Compact (np. PetroChina i indyjska Oil and Natural Gas Corporation) jest też uwikłanych w łamanie praw człowieka w Sudanie ${ }^{47}$.

Przeciwnicy Global Compact za największą słabość inicjatywy uważają to, że opiera się ona na dobrowolnym uczestnictwie. W ich opinii wiara w samoregulację przedsiębiorstw jest naiwna i może przynieść więcej szkody niż pożytku. Ostrej krytyce poddawane są raporty przedstawiane przez uczestników Global Compact. Zarzuca im się ogólnikowość i brak danych świadczących o rzeczywistym zaangażowaniu firm we wdrażanie dziesięciu zasad inicjatywy. System monitoringu uczestników postrzegany jest jako mało efektywny, a sankcje stosowane wobec

${ }^{46}$ Global Compact on BP: "Big Accidents Happen All the Time”, http://globalcompactcritics. blogspot.com/2010 /06/global-compact-on-bp-big-accidents.html, odczyt z 14.11. 2014.

47 Global Compact Participant's Sudan Deals Come under Attack, http://globalcompactcritics. blogspot.com/2008/ 07/global-compact-participants-sudan-deals.html, odczyt z 14.11.2014. 
przedsiębiorstw, które nie realizują, bądź wręcz działają w sprzeczności z założeniami Global Compact za mało dotkliwe ${ }^{48}$. Często w kontekście Global Compact używa się pojęcia bluewashing, które sugeruje, że biznes, wykorzystuje uczestnictwo w tej inicjatywie do tego, aby przywdziać błękitną flagę ONZ i ukryć pod nią swoje nieetyczne postępowanie. Zarzuty, jakie stawiane są wobec Global Compact można streścić, cytując wypowiedź jednego z krytyków, który określił inicjatywę jako: „kolejne, pozbawione mocy sprawczej przedsięwzięcie, które dostarcza przedsiębiorstwom okazji do przyjmowania górnolotnych zobowiązań w zakresie społecznej odpowiedzialności bez obaw, że będą rzeczywiście z nich w jakikolwiek sposób rozliczane"«9.

W obliczu coraz większego nasilenia się negatywnych opinii na temat Global Compact ONZ zdecydowało się wprowadzić kilka istotnych zmian. Od 2009 roku każda firma, która w przeciągu roku nie umieści na stronie inicjatywy swojego raportu z postępu w realizacji dziesięciu zasad, może być z niej wykluczona. Dotychczas z listy uczestników Global Compact zostało w ten sposób usunięte 4804 przedsiębiorstwa ${ }^{50}$. Wprowadzono też trzy poziomy uczestnictwa w inicjatywie: platforma uczących się, poziom uczestników aktywnych i poziom uczestników zaawansowanych, co ma mobilizować przedsiębiorstwa do osiągania coraz to wyższych stopni społecznej odpowiedzialności. Zmiany te nie zadowalają jednak przeciwników Global Compact, a krytyka inicjatywy nie słabnie. Aktywne w tym obszarze są zwłaszcza organizacje społeczeństwa obywatelskiego, które śledzą postępowanie korporacji i wskazują na rozbieżności między założeniami inicjatywy, a działaniem jej uczestników. Dążą w ten sposób do zrewidowania obecnego podejścia ONZ do przedsiębiorstw.

Podsumowując dotychczasowe rozważania, należy stwierdzić, że relacje między ONZ a środowiskiem międzynarodowego biznesu były pochodną układu sił poszczególnych grup państw w obrębie tej organizacji oraz bieżącej sytuacji politycznej, społecznej i gospodarczej świata. Kraje rozwijające się, wykorzystując w latach

48 P. Engardio, Commentary: Global Compact, Little Impact, Business Week, 12 July 2004, http://www.businessweek.com/stories/2004-07-11/commentary-global-compact-little-impact, odczyt z 14.11.2014.

49 Global Compact is Another Exercise in Futility, Financial Express, 7 September 2003, http:// www.financialexpress.com/news/global-compact-is-another-exercise-in-futility/91447/3, odczyt z 14.11.2014.

${ }^{50}$ Stan na 14.11.2014 r., Global Compact Site, https://www.unglobalcompact.org/COP/analyzing_progress/expelled_participants.html, odczyt z 14.11.2014. 
siedemdziesiątych swoją liczebną przewagę w Zgromadzeniu Ogólnym oraz zimnowojenną rywalizację między dwoma supermocarstwami, starały się narzucić ONZ konfrontacyjne podejście do korporacji transnarodowych. Objawiało się to podejmowaniem działań, zmierzających do ograniczania ich aktywności i wzmacnianiu pozycji państwa względem zagranicznych inwestorów. Wraz z przyspieszeniem procesów globalizacji w latach dziewięćdziesiątych przedsiębiorstwa międzynarodowe stały się na tyle silnymi podmiotami, że ONZ było zmuszone podjąć z nimi próbę dialogu i współpracy. W międzyczasie zmieniała się też postawa samych korporacji, które obserwując coraz większą względem nich wrogość, zaczęły zwracać się ku koncepcji społecznej odpowiedzialności biznesu.

Jak dotąd nie udało się wypracować w obrębie ONZ na tyle trwałego kompromisu, który pozwoliłby na jednoznaczne i sztywne uregulowanie działalności przedsiębiorstw międzynarodowych. Źródłem sporu są przede wszystkim kwestie dotyczące obszaru spraw, które powinny być unormowane przez ONZ oraz wiążącego charakteru tych norm. Państwa wysoko rozwinięte nie zgadzają się na przyjęcie rozwiązań o charakterze "twardego" prawa międzynarodowego, dlatego ONZ musi w swojej polityce względem biznesu opierać się na „miękkim” prawie i dobrowolnych inicjatywach takich jak Global Compact. W efekcie tego, działania ONZ są w dużej mierze reakcją na otaczającą rzeczywistość, niż próbą kształtowania jej. Przewartościowanie polityki ONZ w kierunku współpracy z sektorem prywatnym doprowadziło do tego, że organizacja jest oskarżana przez organizacje społeczeństwa obywatelskiego o uległość względem korporacji, a samą ewolucję postawy ONZ można odczytywać jako przejaw słabości tej organizacji. 